\title{
Clam distribution and subsurface hydrothermal processes at Chowder Hill (Middle Valley), Juan de Fuca Ridge
}

\author{
Anthony J. Grehan*, S. Kim Juniper \\ Centre de recherche en géochimie isotopique et en géochronologie (GEOTOP) \& Département des Sciences Biologiques, \\ Université du Québec à Montréal, Case Postale 8888, Succursale Centre-Ville, Montréal (Québec), Canada H3C 3P8
}

\begin{abstract}
This study used seafloor imaging, near-surface sampling and drilling results to examine hydrological constraints on vent organism distribution and productivity in a sedimented hydrothermal setting at Middle Valley, Juan de Fuca Ridge in the northeast Pacific, where venting is focused around seafloor mounds. A vesicomyid clam bed on one of these mounds (Chowder Hill) was reconstructed from imagery acquired by the remotely operated vehicle ROPOS, using a new image enhancement/ mosaicking system. The mosaic was fitted to a Universal Trans-Mercator (UTM) coordinate grid and a contour map of clam density and local bathymetry was derived from visual counts within grid squares and ROPOS navigation logs. Highest clam density occurred on a slightly raised area of seafloor in the upper-central portion of the clam bed, where sediment temperatures suggested hydrothermal flux to be greater than further downslope. Results from Ocean Drilling Program (ODP), College Station, Texas, USA, Leg 139 suggested that a local hydrothermal reservoir exists within Chowder Hill and that erosion of low-permeability surface sediments may be critical to allowing fluids to escape. A 1-dimensional advection-diffusion model was used to derive an estimate for $\mathrm{H}_{2} \mathrm{~S}$ supply to the clam bed from a subsurface reservoir, based on sediment temperature profiles and pore-water $\mathrm{H}_{2} \mathrm{~S}$ concentrations. Estimated $\mathrm{H}_{2} \mathrm{~S}$ flux ( $250 \mathrm{~mol} \mathrm{~m}{ }^{-2} \mathrm{Yr}^{-1}$ ) would support a maximum chemosynthetic $\mathrm{CO}_{2}$ fixation rate of $8.3 \mathrm{gC} \mathrm{m}^{-2} \mathrm{yr}^{-1}$. More detailed in situ data are required to study links between local fluid flow variations and clam density, and to resolve near-surface processes that laterally delimit the fluid conduit beneath the clam colony.
\end{abstract}

KEY WORDS: Hydrothermal vents Calyptogena $\cdot$ Mosaicking · Fluid flux

\section{INTRODUCTION}

Hydrothermal vent sites are characterized by irregular topographical and physicochemical features and extreme patchiness of animal distribution (e.g. Hessler et al. 1985, Chevaldonné \& Jollivet 1993). A high degree of accommodation to environmental controls appears to be a predominant feature of vent communities (Hessler et al. 1985, Fustec et al. 1987, Tunnicliffe \& Juniper 1990), although significant influences of biotic interactions on community composition cannot yet be discounted (e.g. Hessler et al. 1988). Understanding mechanisms by which environment influences vent community pattern-

\footnotetext{
- Present address: Zoology Department, Martin Ryan Science Institute, University College, Galway, Ireland

E-mail: anthony.grehan@ucg.ie
}

ing has advanced little beyond the descriptive stage, primarily because of difficulties inherent in obtaining corresponding ecological, physicochemical and geological data. Recent initiatives by the RIDGE and InterRidge programs (RIDGE Office, University of New Hampshire, Durham, $\mathrm{NH}$, USA; InterRidge Office, University of Durham, Durham, UK) to foster multidisciplinary investigations at designated ridge crest observatories (Delaney \& Hildebrand 1993) represent a promising development for ecologists. The coordinated acquisition of biological and environmental data at vent and vent field scales should greatly improve our ability to reconstruct spatial and temporal relationships between vent organisms and potential environmental controls, and so critically evaluate their interaction. Some observatory studies are already under way (Juniper et al. 1994), while others are in the planning stages. 
Photographs and video imagery are a primary source of data for reconstructing benthic organism distribution and surface geological features at vents and seeps (e.g. Juniper \& Sibuet 1987, Hessler et al. 1988). Recent developments in video capture and image processing technology for personal computers greatly increase the speed and ease with which image mosaic 'maps' can be produced. The application of computer-assisted mosaicking by MacDonald et al. $(1989,1994)$ to document spatial distribution of organisms around gas seeps in the Gulf of Mexico illustrates the potential of this technology for vent ecological studies. Synoptic mapping of temperature and chemical conditions at hydrothermal vents will also soon benefit from a recent technological development. Submersible flow injection chemical scanners have been used to probe the microenvironment around some vent species (Johnson et al. 1986, 1988, Sarrazin et al. 1993), and to map hydrothermal plumes (Massoth et al, 1995), and are a promising tool for vent field scale chemical mapping.

Reconstruction of seafloor features from submersible gathered data provides a 2-dimensional view of what is essentially a 3-dimensional hydrological and ecological problem. Subsurface processes that control hydrothermal fluid emission are understood in a descriptive sense, but since they occur beneath the floor of the deep ocean, direct observation is difficult and real 3-dimensional information on vent field hydrology is rare. Recent and planned scientific drilling operations by the Ocean Drilling Program (ODP), College Station, Texas, USA at hydrothermal vent sites provide unique opportunities for ecologists to add this third dimension to their view of processes determining community patterning. This paper follows up on a predrilling study of hydrothermal communities at Middle Valley, on the Juan de Fuca Ridge in the Pacific Ocean off the US/Canadian coast (Juniper et al. 1992). Here, we developed an approach to reconstruct a vesicomyid clam bed and its local geological setting, using imagery and samples collected by the remotely operated vehicle ROPOS and published information from ODP Leg 139. Particular emphasis was placed on near-surface processes controlling fluid supply to the clams. The paper also describes a Macintosh-based image processing and mosaicking system that we developed for this work, and discusses problems associated with mosaicking and image analysis.

\section{Site description}

At Middle Valley, a failed rift at the northeastern end of Juan de Fuca Ridge, venting occurs through several hundred meters of interbedded turbidite and hemipelagic sediment. The principal centre of present day hydrothermal activity in Middle Valley is the Dead Dog vent field (the 'High Heat Flow Area' in Juniper et al. 1992), where venting is concentrated around 5 to $18 \mathrm{~m}$ high sediment-covered mounds (Fig. 1). High temperature chimneys (up to $276^{\circ} \mathrm{C}$ ) are restricted to mound summits. Diffuse low temperature flows $\left(<40^{\circ} \mathrm{C}\right)$ that support microbial mats and symbiont-bearing bivalve communities (Calyptogena spp., Solymya spp.) are found in basal and flank areas of active mounds (Juniper et al. 1992). The largest bivalve colony known is located on the lower northwestern slope of a $15 \mathrm{~m}$ high, $60 \mathrm{~m}$ diameter mound known as Chowder Hill (Fig. 1). The colony is dominated by a large symbiontbearing vesicomyid clam designated Calyptogena large (n. sp. 2) by Juniper et al. (1992). In the summer of 1991 , Hole $858 \mathrm{~B}$ of ODP Leg 139 was drilled to a depth of $32 \mathrm{~m}$ on the northeastern flank of Chowder Hill (Fig. 1), and several deeper holes were drilled nearby (Davis et al. 1992). Subsurface processes were investigated through analysis of physical and chemical properties of drill core material and downhole observations. Related piston coring, seismic and heat flow studies, and drilling at 3 other sites in Middle Valley provided vent field and regional scale information on the nature and consequences of hydrothermal circulation (Davis et al. 1992, 1994).

\section{MATERIALS AND METHODS}

Image collection and navigation. Images (both video and still photos) of the Chowder Hill site were collected by the ROPOS remotely operated vehicle during a 1992 joint Canada/US expedition to the Juan de Fuca Ridge aboard the NOAA 'Discoverer' (Embley \& Franklin 1993). A total of 4 dives visited the clam bed on Chowder Hill (HYS-192, 193, 196 and 199), between June 27 and July 4 . The bulk of the results discussed here are from detailed mapping carried out during dive HYS-199. During imaging transects in dive HYS-199, the ROPOS was flown laterally, facing the slope at a constant altitude with the Silicon Intensified Targetting (SIT) camera pointing vertically down. Lateral movement minimized resuspension of sediments over the target area, permitting repetition of imaging swaths without visibility loss.

Video imagery from the ROPOS black and white SIT and Osprey colour cameras was recorded in the industrial chrominance/luminance (Y/C) format (S-video). Colour still photos were taken on Kodak negative transparency film, using a Photosea $35 \mathrm{~mm}$ camera. Definition of the boundaries of the clam bed study area within a Universal Trans-Mercator (UTM) coordinate system was based on acoustic transponder navigation of the ROPOS, relative to differential Global Positioning System (GPS) positioning of the surface support vessel. 
Image analysis and treatment. The sea-going image analysis system included a Macintosh IIci upgraded to a $100 \mathrm{MHz}$ Power PC (48 MB RAM, $240 \mathrm{MB} \mathrm{HD)}$ with an onboard 24-bit, S-video capable colour image capture card (RasterOps 24TVX) with compatible software: Adobe Photoshop 3.0 (image capture and enhancement) and IPLab Spectrum 2.5.7 (image enhancement, sizing, rotation and mosaicking and on-screen measurement; Signal Analytics Corporation). Peripherals included a Dynatec RMD88 removable hard drive for storage of captured video images (up to 2 or $3 \mathrm{MB}$ for 24 -bit colour images) and an Apple CD-ROM 300 for viewing digitized still photos. On-line image capture from the ROPOS cameras was possible during dives, but most mosaicking work was done from recorded video. Recordings were initially reviewed using a paired Panasonic AG5700 S-VHS VCR and high resolution monitor system enabling synchronized viewing of SIT and colour video. Selection and control of video sequences for image capture was facilitated by using a Panasonic AG-A570 editing board. Photographs (slides) were digitized commercially using the Kodak proprietary PhotoCD process.

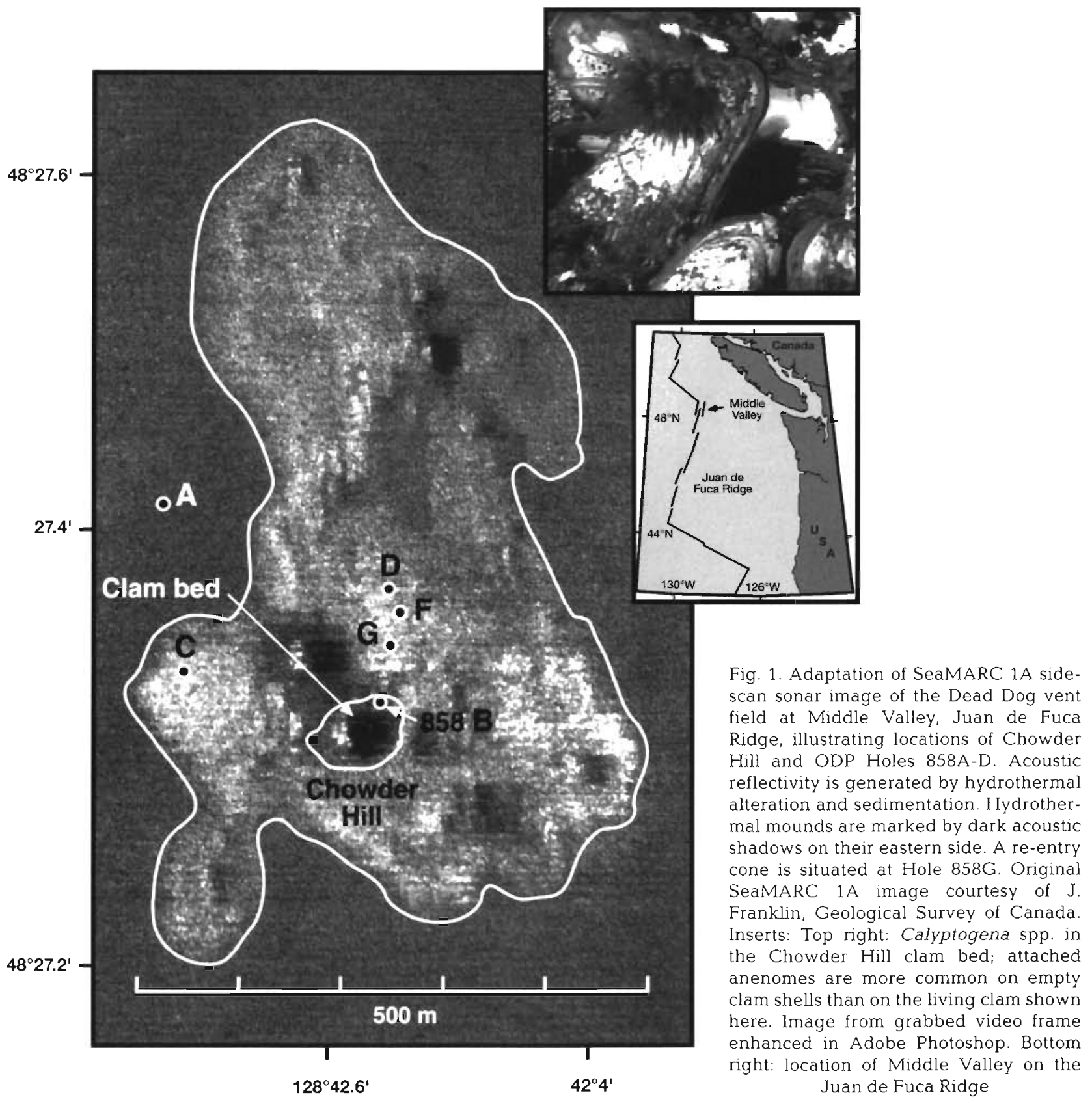


Digitized video frames were reviewed after appropriate enhancement (brightness, contrast, sharpness) using Adobe Photoshop or IPLab Spectrum. Repetitive enhancement tasks were usually scripted with Spectrum, greatly speeding up image processing. Automated edge finding and object recognition, both based on pre-determined brightness criteria, could also be scripted in Spectrum.

Mosaicking. IPLab Spectrum was used to create a composite black \& white image of the clam bed from SIT video frames selected from east-west transects (HYS-199). Beginning with a single pair of overlapping images, a mosaic was built up by fitting successive daughter images to the expanding parent image. For each pairing, at least 2 common objects in each image were selected on-screen using the registration tool in Spectrum. From these registration marks, Spectrum automatically calculated and performed the necessary scaling and rotation to fit the daughter image to the mosaic. While overlapping images taken from a constant altitude should theoretically fit together seamlessly, sizing and rotation was inevitably necessary to correct for minor altitude variations and vehicle yaw between successive images. The final merging of parent and daughter images was then performed in Spectrum with the mosaic function, using the same registration marks, or by exporting prepared daughter images to Photoshop where temporary lowering of opacity eased positioning onto the mosaic. Illumination and contrast in the completed mosaic were optimized in Photoshop, and the final image was reproduced on a Linotronic printer at $2400 \mathrm{dpi}$ (dots per inch).

Grid positioning. Two navigational reference points were established at opposite ends of the clam bed during dive HYS-199. Each point corresponded to the mean UTM $x, y$ position of the ROPOS vehicle during 5 min holds at the start and finish of an east-west video transect. Video imagery was then used to identify these 2 points on the final mosaic, where they were fixed as registration marks. Next, a $50 \mathrm{~cm}$ mesh UTM navigational grid was drawn using Aldus Freehand and imported into Spectrum where registration marks were placed on the $x, y$ positions of the 2 reference points. The mosaic was then scaled and rotated to fit the navigational grid and the paired images were exported to Adobe Photoshop where the grid was overlaid on the mosaic.

Density measurements. Uneven illumination in our images prevented any meaningful experimentation with brightness-based automated object recognition for counting clams. Instead, counts were made directly by eye from high resolution photo and colour video images correctly scaled and positioned within the clam bed. This was accomplished by using the mosaic as a template to scale high resolution images and locate them within the UTM grid. A copy of the grid was then overlaid on the high resolution image and used to count clams. Count and position data were contoured with MacGridzo, using the $x, y$ position of the centre of each counted image as the location of the data point.

Geological observations and sampling. Local geology around the clam bed was studied by reviewing video sequences from all dives on Chowder Hill. Temperature profiles were taken at 2 sites in the clam bed during dives HYS-192 (2 replicate profiles in upper clam bed) and HYS-199 (single profile in lower clam bed). Profiles were taken by first measuring temperature next to the sediment surface using a high temperature probe, and then inserting the probe vertically into the sediment, stopping at 7,19 and $29 \mathrm{~cm}$ depth for readings. During dive HYS-192, the submersible collected 4 live clams at the site of the replicate temperature profiles. A push-core was taken next to the temperature profile site during dive HYS-199, where a PVC tripod marker was also deployed.

Local bathymetry for a $20 \times 15 \mathrm{~m}$ area around the clam bed was determined from $x, y, z$ data in ROPOS dive logs, using only data points where ROPOS was sitting on the bottom for at least $2 \mathrm{~min}$. Average $x, y$ position for each time interval was used to place each depth point in space for contouring with MacGridzo.

\section{RESULTS}

\section{Clam bed map}

The final image composite with the overlaid navigational grid is shown in Fig. 2a. Image resolution was reduced by over-illumination in the centre of the clam bed where reflection from shell debris and bacterial mat saturated the SIT camera. Some recovery of detail was achieved through enhancement, but much textural information was masked by the high reflectivity. Overall image quality was still sufficient for the intended purposes of outlining the clam bed and acting as a base map to locate high definition images of the clams. The clam bed was situated on the northeastern corner of Chowder Hill between 2414 and $2415 \mathrm{~m}$ and generally ran along slope, covering a surface area of approximately $28 \mathrm{~m}^{2}$ The locations of the 2414 and $2415 \mathrm{~m}$ depth contours within the clam bed are shown in Fig. 2 b.

\section{Density measurements}

Clam density distribution over the entire bed is contoured in Fig. 2b. Highest densities were encountered in the central and upslope areas. Downslope, clam densities gradually fell off as one approached the 
a.

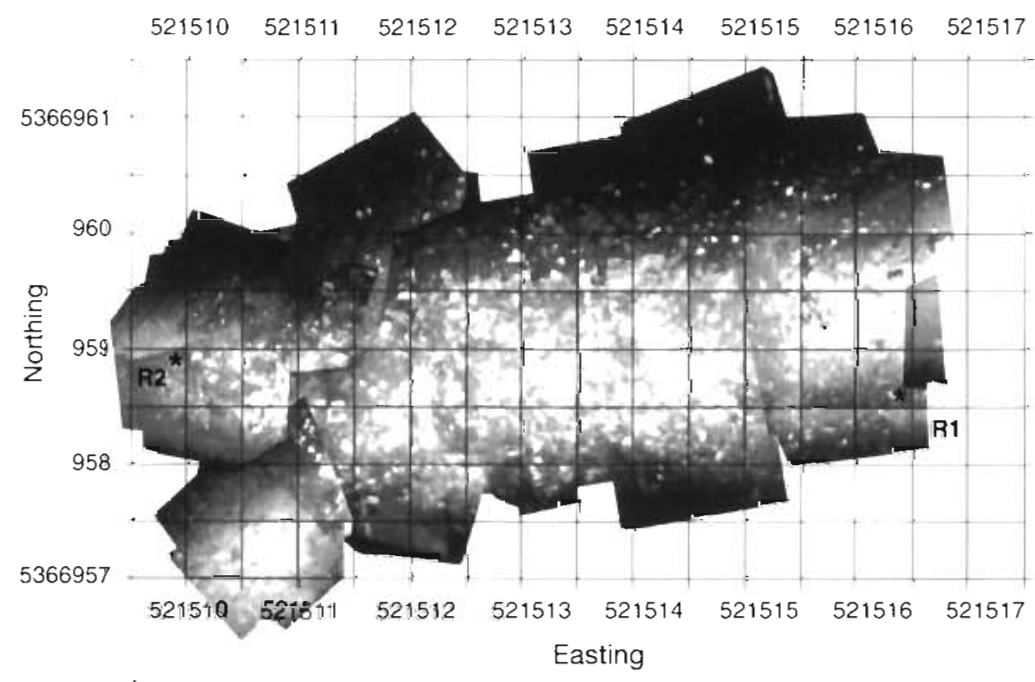

b.

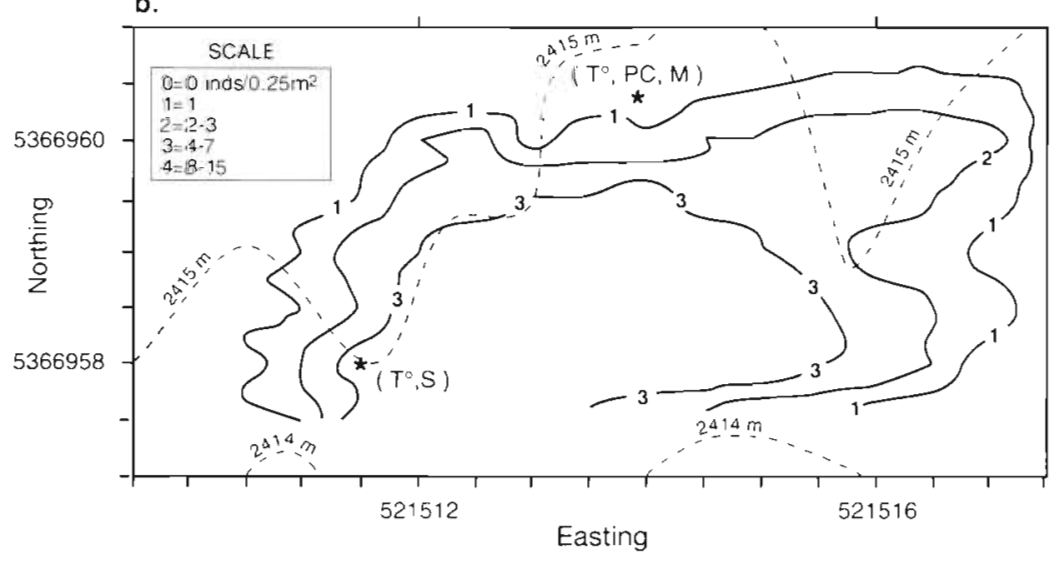

Fig. 2. (a) Enhanced video mosaic of Chowder Hill clam bed with overlaid UTM grid. Navigation reference points used to align mosaic to grid are shown (R1, R2). (b) Contour map of clam density derived from counting clams in selected UTM grid squares. Approximate locations of 1992 ROPOS temperature profiles $\left(T^{\circ}\right)$, push-core sample (PC), clam sample (S) and PVC tripod marker deployment (M) are indicated. - . - - locations of 2414 and $2415 \mathrm{~m}$ depth contours

of the mound. The platform was strewn with boulders and cobble-sized chunks of indurated mud rich in pyrite and hydrocarbons. The cobble-sized pieces may have been fragments of a surface crust broken up by clam movement. The presence of the platform appeared to be reflected in the northward extension of the $2415 \mathrm{~m}$ depth contour in the central area of the clam bed (Fig. 2b). The zone of highest clam density overlaid this locally upraised area of seafloor (Fig. 2b).

Temperature profiles are illustrated in Fig. 3. Although all profiles were very crudely constrained, it is worth pointing out that the 2 profiles taken in the upper portion of the slope suggested greater fluid flow rates, compared to the downslope site. This corresponded to the greater estimated density of clams in the upslope portion of the field. The temperature gradient suggested by these profiles (ca $18^{\circ} \mathrm{C}$ $\mathrm{m}^{-1}$ ) was roughly twice the background value in the vent field away from the mounds and similar to the highest conductive values observed by Davis \& Villinger (1992). The more rapid temperature drop in the upper few $\mathrm{cm}$ of the HYS-197 profiles may have reflected the entrainment of seawater in the rubbly surface layers in this area of the mound.

The push-core taken by ROPOS at the downslope site was analyzed for pore water chemistry. Pore fluids were extracted by centrifugation of pooled

hemipelagic mud of the seafloor surrounding Chowder Hill. There were an estimated 200 clams in the bed, of which an estimated 150 were in the upright 'living' position, as determined from examination of still photos. Highest densities encountered in quadrats were 20 ind. $\mathrm{m}^{-2}$. Distribution was discontinuous, giving average densities of about 5 ind. $\mathrm{m}^{-2}$. Shell length of sampled clams ranged from 7.0 to $18.1 \mathrm{~cm}$ and maximum shell width was 3.8 to $7.3 \mathrm{~cm}$, yielding respective means of 14.5 and $6.3 \mathrm{~cm}(\mathrm{n}=4)$.

\section{Local geology}

Relative to the slope and the surrounding seafloor, the clam colony appeared to be situated on and around a platform produced by slumping or localized inflation sediments from 0 to 4 and 4 to $8 \mathrm{~cm}$ depth intervals. Pore fluid $\mathrm{H}_{2} \mathrm{~S}$ values from Butterfield et al. (1994) are given in Fig. 4.

\section{DISCUSSION}

\section{Clam colonies and sulfide supply}

Vesicomyid clam colonies are found in both vent and seep environments in the deep sea, wherever the supply of $\mathrm{H}_{2} \mathrm{~S}$ is sufficient to support chemosynthesis by their endosymbionts, and where there is a suitable substratum (Kennish \& Lutz 1992). Sediments receiving a diffuse supply of reducing fluids are the most common substratum colonized by these clams (Kennicutt et al. 1985, Sibuet et al. 1988, Juniper et al. 1992), although 




Fig. 3. Temperature profiles in Chowder Hill clam bed from data collected with high-temperature probe on ROPOS remotely operated vehicle

certain basalt terrains can also be exploited (Hessler et al. 1985). Colony size and relative abundances of living and dead clams appear to be linked to site longevity and constancy of fluid supply (Juniper \& Sibuet 1987). Adequate supply of sulphide is obviously of critical importance to the clams, although low ambient levels can be compensated by an ability to concentrate sulphide (Arp et al. 1984). The upper limits to clam colonization may be set by the animals' ability to detoxify $\mathrm{H}_{2} \mathrm{~S}$. FialaMédioni et al. (1993) indicate that vesicomyid clams do not colonize sites where pore-water $\mathrm{H}_{2} \mathrm{~S}$ concentrations exceed $1 \mathrm{mM}$. Species-specific limits in terms of ambient $\mathrm{H}_{2} \mathrm{~S}$ levels and resupply rates are poorly understood, although there is some recent evidence for environmental control of composition and density of clams within colonies and the overall 2-dimensional shape of the colony, as discussed below.

Some workers have classified cold seep clam colonies based on colony morphology, clam size and clam density (e.g. Sibuet et al. 1988, Henry et al. 1992) and related these characteristics to environmental variables. Relevant to this study is the relationship between clam size and density and fluid flow velocity and flow pattern determined by Henry et al. (1992), whose classification scheme described a 'Type $C^{\prime}$ colony as being composed of large half-buried clams at low density (30 ind. $\mathrm{m}^{-2}$ ) that co-occur with white bacterial mats, supported by slow seepage ( $\left.<10 \mathrm{~m} \mathrm{yr}^{-1}\right)$ of $\mathrm{H}_{2} \mathrm{~S}$ rich fluid. The Chowder Hill clam bed shared similarities with the 'Type $C^{\prime}$ colony, both in clam size and density. The thermal gradient at Chowder Hill was, of course, much steeper than that observed by Henry et al. (1992) in a subduction zone setting, as a result of both conductive and advective heat flow from a shallow, high-temperature reservoir, as discussed below. The Chowder Hill clams generally appeared to be half-inserted in the sediments, and with an average shell length of $14.5 \mathrm{~cm}$, most should have been in direct contact with pore fluids in the sampled 4 to $8 \mathrm{~cm}$ layer (see Fig. 4 inset). Levels of $\mathrm{H}_{2} \mathrm{~S}$ in pore waters in


the $1 \mathrm{mmol} \mathrm{kg}^{-1}$ upper limit for vesicomyid clams proposed by Fiala-Médioni et al. (1993). White bacterial mats were present within the Chowder Hill clam bed, although their significance as indicators of flow regime in a sedimented hydrothermal situation is not clear. Henry et al. (1992) described 2 distinct types of flow regime, distinguished by differences in flow rate and in dilution of original pore fluids by seawater in the upper layers of sediment. Their analyses showed dilution to be controlled by 2 factors: the lateral permeability of the fluid conduit and the relationship between volume flow and conduit diameter. In the following section, we examine results from the drilling program in Middle Valley, in order to develop a conceptual model of the processes that create a 'Type $C^{\prime}$ venting situation at the Chowder Hill clam bed.

\section{Subsurface processes in the Dead Dog field}

Seismic profiles across the Dead Dog vent field in Middle Valley indicated the presence of a prominent basement fault, approximately $2 \mathrm{~km}$ to the east of the vent field (Rohr \& Schmidt 1994). Fluids presently venting at the Dead Dog field showed chemical signatures of interaction with both basaltic and sedimentary rock (Butterfield et al. 1994, Goodfellow \& Peter 1994) and were believed to originate within a sill-sediment complex that formed the transition to oceanic crust in the area of the fault block (Davis et al. 1992). The sillsediment reaction zone was buried by $450 \mathrm{~m}$ of hemipelagic sediment. A volcanic edifice located immediately beneath the Dead Dog field reached to within $250 \mathrm{~m}$ of the seafloor and has been proposed to act as a chimney to direct hydrothermal fluid flow 




Surtace
sediments

Fig. 4. The northern face of Chowder Hill (looking south). Schema (not to scale) summarizes observations and hypotheses regarding local hydrothermal circulation (main figure), and fluid supply to the clam colony (enlargement)

upward from the reaction zone (Davis \& Fisher 1994). The sediment cover surrounding and overlaying the volcanic edifice was apparently more hydrologically resistive than the edifice itself (Davis \& Fisher 1994). Packer experiments in Hole 858G that penetrated the edifice showed it to be sufficiently permeable $\left(2 \times 10^{-14}\right.$ $\mathrm{m}^{2} ;$ Becker et al. 1994) to act as a conduit for hydrothermal fluids from the regional basement reservoir.

From the top of the intrusive edifice to the seafloor, fluid migration appears to depend on hydrothermal alteration (lithification) of the sediment cover, and resultant fracturing (Goodfellow \& Peter 1994, Leybourne \& Goodfellow 1994). The effective bulk permeability of the column of altered sediments overlaying the edifice at Site 858 (Dead Dog field) may be up to an order of magnitude greater than for sediments with only minor alteration $\left(10^{-15} \mathrm{~m}^{2}\right.$ vs $10^{-16} \mathrm{~m}^{2}$; Davis \& Fisher 1994). These highly altered sediments reached to within 25 to $30 \mathrm{~m}$ of the seafloor, where seismic reflection data showed an abrupt transition to a surface layer of physically unaltered sediments (Rohr \& Gröschel-Becker 1994j. Drill core samples indicated the presence of a layer of extreme induration in this transition zone (Davis et al. 1992). The highly indurated layer marked the upper boundary of a high temperature $\left(280^{\circ} \mathrm{C}\right)$ fluid reservoir that Davis \& Fisher (1994; Fig. 9) depicted as an isothermal column extending up from the basement edifice into the altered sediments. Vertical conduits feeding seafloor vents would thus originate at the top of the sediment reservoir.

Davis \& Fisher (1994) did not specifically address the processes that locally increase permeability in the upper 25 to $30 \mathrm{~m}$ of sediment and provide conduits for venting. One possibility is that these final few metres of fluid advection depend upon the same processes of sediment induration and fracturing that control fluid movement in deeper sediments. Outcroppings of indurated sediment are common in the Dead Dog field, particularly on the sides of the mounds, and many are venting fluids that support tube worm communities (Juniper et al. 1992, S. K. Juniper unpubl. obs.). Further support for a link between hydrothermal alteration of surface sediments and venting comes from observations that venting in the Dead Dog field occurred primarily on the slopes and summits of the mounds (Juniper et al. 1992). Goodfellow \& Peter (1994) and Turner et al. (1993) described a high degree of hydrothermal alteration of mound sediments that contrasted with the generally unaltered condition of the upper 25 to $30 \mathrm{~m}$ of sediment within the vent field as a whole. The very presence of the mounds themselves is likely a result of the alteration process. Turner et al. (1993) proposed that the mounds grow by inflation related to fluid overpressures and mineral precipitation, or that the structural stability imparted to them 
by hydrothermal alteration permits the mounds to progressively 'grow' as thermal dewatering of sediments causes subsidence of the surrounding seafloor.

\section{Subsurface processes at Chowder Hill}

We considered how fluids might be expelled at the clam bed at Chowder Hill, within the above context of hydrothermal alteration of sediments and related permeability changes. The irregular distribution of venting on Chowder Hill indicated that permeability properties are not homogeneous over the entire structure. Clues to one aspect of local permeability control may be found in 2 observations. Hole $858 \mathrm{~B}$ penetrated the northeast flank of Chowder Hill to a depth of $32 \mathrm{~m}$. When observed by submersible the following year, Hole $858 \mathrm{~B}$ was venting high temperature fluids from a chimney that had formed on the side of the hole, at 1 to $2 \mathrm{~m}$ below the seafloor surface ( $\mathrm{K}$. Becker pers. comm.). This observation suggested that a locally shallow reservoir of high temperature fluids resided within the mound and that widespread venting was prevented by a low permeability surface layer. The localization of the clam bed on a slump scar, where indurated sediments were exposed, can be seen as further evidence of a local reservoir within the mound. In the case of the clam bed, we suggest that erosion has brought more permeable sediments close enough to the seafloor to supply the clams with $\mathrm{H}_{2} \mathrm{~S}$ through slow diffusion into the soupy surface layer (Fig. 4)

The absence of detectable temperature anomalies at the sediment surface within the clam bed and the modest temperatures measured down to near $30 \mathrm{~cm}$ were evidence of the relatively low intensity of venting at this site. The sediment layer supplying the clam bed may have been less permeable to fluid flow than the conduit exposed at nearby Hole $858 \mathrm{~B}$ or the conduit feeding the high temperature $\left(276^{\circ} \mathrm{C}\right)$ vents further up the hill. As discussed above, the relatively low density of clams within the Chowder Hill field was also indicative of low velocity venting, although predation effects on clam density by the locally abundant octopus population (Juniper et al. 1992) are unknown.

The same fracture-enhanced permeability that opened sediments to the movement of hydrothermal fluid also permitted entrainment of seawater into the conduit system. Magnesium enrichment of hydrothermally alterated sediments recovered from cores on Chowder Hill indicated that seawater entrainment does occur (Goodfellow \& Peter 1994, Leybourne \& Goodfellow 1994). We do not have sufficient data to model the level of seawater entrainment into the conduit system, as performed by Henry et al. (1992) for clam colonies at subduction zone seeps. Comparison of sulfide and $\mathrm{Si}$ concentrations from Butterfield et al (1994) for pore waters from the 4 to $8 \mathrm{~cm}$ layer in the clam bed $\left(0.489\right.$ and $1.243 \mathrm{mmol} \mathrm{kg}^{-1}$, respectively) with the $276^{\circ} \mathrm{C}$ fluids sampled from the top of Chowder Hill (1.82 and $9.61 \mathrm{mmol} \mathrm{kg}^{-1}$, respectively) indicated that the fluid source feeding the clam bed was formed by mixing of high temperature fluids and entrained seawater. Modeling of seawater entrainment requires more extensive pore-water and temperature profile data for the clam bed and surrounding sediments. In Fig. 4, we present a simplified scheme for permeability control of fluid supply to the clam bed on Chowder Hill that summarizes the observations discussed above.

\section{Fluid and sulfide flow to the clam colony}

Measured sediment temperature profiles (Fig. 3) and pore-water sulfide concentrations (Fig. 4 inset) can be used to constrain flow characteristics for the clam bed, and to derive an estimate of sulfide supply to the colony from a subsurface source. For this purpose, we first estimated fluid flow velocity from the temperature gradient using the equations of Bredehoeft \& Papadopolus (1965) for a 1-dimensional advection-diffusion model. This steady-state model assumes vertical uniform flow of fluid and heat through a homogeneous and fully saturated semiconfining layer from a source at depth $L$. Thermal conductivity for the sediments was taken from data from the 858B drill core (average value of $1.0 \mathrm{~W} \mathrm{~m}^{-1} \mathrm{~K}^{-1}$; Davis et al. 1992). Because temperature was measured to a shallow depth only $(z=29 \mathrm{~cm})$, it was not possible to fit the temperature profiles to theoretical exponential profiles for advection such as given in Bredehoeft \& Papadopulus (1965). Instead, we expanded their solution for shallow depth intervals $(\beta z / L \ll 1.0)$ over which the temperature gradient can be assumed to be linear. Given this boundary condition, for an average temperature gradient of $18^{\circ} \mathrm{C} \mathrm{m}^{-1}$ (Fig. 3), the calculation of fluid velocity was reduced to the following equation

$$
V_{z}=\frac{18^{\circ} \mathrm{k}}{c \rho\left(T_{L}-T_{0}\right)} 3 \times 10^{7} \mathrm{~s}
$$

where $V_{z}=$ fluid velocity $\left(\mathrm{m} \mathrm{yr}^{-1}\right) ; k=$ thermal conductivity $\left(1.0 \mathrm{~W} \mathrm{~m}^{-1} \mathrm{~K}^{-1}\right) ; c=$ specific heat of fluids $\left(4000 \mathrm{~J} \mathrm{~kg}^{-1}\right) ; \rho=$ density of fluids $\left(10^{3} \mathrm{~kg} \mathrm{~m}^{-3}\right) ; T_{L}=$ source fluid temperature at depth $L_{i} T_{0}=$ temperature at sediment-seawater interface $\left(2^{\circ} \mathrm{C}\right)$

Estimates of $V_{2}$ by this method are sensitive to the choice of source temperature $\left(T_{L}\right)$, which could not be measured directly. The maximum source fluid temperature was assumed to be $280^{\circ} \mathrm{C}$, corresponding to a high temperature reservoir at $30 \mathrm{~m}$ depth (Davis \& Fisher 1994). For a $280^{\circ} \mathrm{C}$ source a 1 -dimensional 
Darcy velocity of $0.50 \mathrm{~m} \mathrm{yr}^{-1}$ would account for the observed temperature gradient. Lower source fluid temperatures would result in higher fluid velocity estimates (e.g. $1.38 \mathrm{~m} \mathrm{yr}^{-1}$ for a $100^{\circ} \mathrm{C}$ source).

Implicit in this approach was the assumption that no heat is lost through the sides of the conduit bringing fluid to the clam colony. According to Henry et al. (1992) this is acceptable if the depth to $T_{L}$ (fluid source) is small with respect to colony diameter. As this is not the case (colony diameter $\approx 3.5 \mathrm{~m}$, vs source depth of 10 to $30 \mathrm{~m}$ ), the amount of fluid flowing through the colony is underestimated. Fluid flux would be overestimated in the case where the measured thermal gradient was primarily due to vertical conduction above a very shallow aquifer or lateral conduction away from a vertical conduit.

The estimated value was comparable to the minimum velocity of $\sim 0.5 \mathrm{~m} \mathrm{yr}^{-1}$ required to maintain the average temperature profile for the Dead Dog field (Davis \& Fisher 1994) and the $<10 \mathrm{~m} \mathrm{yr}^{-1}$ value estimated for the 'Type C' colonies by Henry et al. (1992). Assuming that fluids feeding the clam colony at a rate of $0.50 \mathrm{~m} \mathrm{yr}^{-1}$ have $\mathrm{a}_{2} \mathrm{~S}$ concentration of $500 \mathrm{mmol} \mathrm{kg}^{-1}$ (see Fig. 4) and a density of $1000 \mathrm{~kg} \mathrm{~m}^{-3}$, the supply rate would be $250 \mathrm{~mol} \mathrm{H}_{2} \mathrm{~S} \mathrm{~m}^{-2} \mathrm{yr}^{-1}$. If all sulfide were used by chemosynthetic bacteria for $\mathrm{CO}_{2}$ fixation, at a molar consumption ratio of 0.35 to $0.40 \mathrm{~mol} \mathrm{CO}_{2}$ fixed per mole $\mathrm{H}_{2} \mathrm{~S}$ consumed (Tuttle \& Jannasch 1979, Nelson \& Hagen 1995), the potential $\mathrm{CO}_{2}$ fixation rate would be $8.3 \mathrm{gC} \mathrm{m}^{-2} \mathrm{yr}^{-1}$. There are no data in the literature that would enable us to estimate the relative importance of the different mechanisms of sulfide oxidation likely to occur in a clam bed (clam symbionts vs free-living bacteria and chemical oxidation). By way of comparison, Juniper et al. (1995) report $\mathrm{CO}_{2}$ fixation rates of up to $6.1 \mathrm{gC} \mathrm{m}^{-2} \mathrm{yr}^{-1}$, for bacterial mats at diffuse vents on the CoAxial Segment of the Juan de Fuca Ridge.

\section{CONCLUSION}

\section{Mosaicking}

Although relatively expensive, custom-designed image mosaicking Geographic Information Systems (GIS) can be developed to carry out small-scale benthic mapping, e.g. the Small Area Benthic Imaging System (SABIS) described by MacDonald et al. (1992), no attempt has previously been made to design a system that exploits the vast potential for application of commercial art and machine vision software and hardware to the particular problems of deep-sea ecology and geology. The system configured here was relatively inexpensive, albeit less sophisticated than dedicated systems. By making use of the intuitive Macintosh GUI (Graphic User Interface) it permits first-time users to gain a basic work- ing familiarity with the mosaicking and image enhancement software, while leaving considerable room for program customization (scripting) by more experienced users. While the mosaicking work can be performed with off-the-shelf personal computers, additional random access memory (RAM) is required to assemble large image mosaics and perform enhancements. The $48 \mathrm{MB}$ of RAM in the system described here is adequate for most tasks involving mosaics of up to 100 images. Use of virtual memory on the computer hard disk considerably slows processing operations.

Systematically repeated and overlapping imaging swaths, controlled viewing angle (preferably $90^{\circ}$ ) and correct illumination are essential if mosaicking is to be used for site reconstruction and quantitative study of vent communities. Here we used natural objects as references for overlapping image pairs and assembling mosaics, and results were satisfactory. While greater accuracy can theoretically be obtained by referencing deployed markers of a constant size and shape (preferably round), it is not always practical or desirable to saturate an area with enough markers to have several appear in every image.

\section{Application of drilling results to ecological studies}

The vast amount of information now available for Middle Valley, and a scheduled second drilling leg for 1996, effectively make this site a de facto ridge crest observatory. A recent RIDGE/USSAC workshop developed plans for coordinated geophysical, geochemical and ecological observations to be carried out in conjunction with the second drilling leg (Zierenberg et al. 1994). Combining results from ODP Leg 139 with submersible observations certainly provided a clearer overall understanding of the processes controlling hydrothermal fluid supply to the clam colony on Chowder Hill. Complementary vent discharge and organism abundance data will also be important to future determinations of energy flow in this hydrothermal ecosystem. Nevertheless, the scale at which hydrological processes are considered in the context of the drilling program does not always correspond to the interests of ecological studies of individual colonies of vent animals. In the latter case, more detailed in situ data gathering is required, in order to better resolve finescale, near-surface processes and to fit them into the general hydrological scheme derived from drilling results. Evaluating the influence of hydrothermal flux on vent community composition in the Dead Dog field will obviously require information from many contrasting sites. It was the intention of this study to develop a methodological approach that will permit acquisition of the necessary comparative data in subsequent studies. 
Acknowledgements. This work was funded by NSERC Canada, the Department of Natural Resources Cariada and the Université du Québec à Montréal. A.J.G. was supported by a post-doctoral fellowship from the Université du Québec. The NOAA Vents program contributed significantly to our field effort. We thank the ROPOS team and the crew of the NOAA 'Discoverer' for their collaboration at sea. Discussions with J.-C. Maréschal and E. Davis were of great aid in the development of the fluid flow estimate. Three anonymous reviewers contributed to improving an earlier version of this manscript. Graphics are by Enriette Gagnon.

\section{LITERATURE CITED}

Arp AJ, Childress JJ, Fisher CR (1984) Metabolic and blood gas transport characteristics of the hydrothermal vent bivalve, Calyptogena magnifica. Physiol Zool 57:648-662

Becker K, Morin RH, Davis EE (1994) Permeabilities in the Middle Valley hydrothermal system measured with packer and flow meter experiments. In: Davis EE, Mottl $M J$, Fisher AT et al. (eds) Proceedings of the Ocean Drilling Program (ODP), College Station, TX, Scientıfic Results 139:613-626

Bredehoeft JD, Papadopulos IS (1965) Rates of vertical groundwater movement from the earth's thermal profile. Water Res 1:325-328

Butterfield DA, McDuff RE, Franklin JM, Wheat CG (1994) Geochemistry of hydrothermal vent fluids from Middle Valley, Juan de Fuca Ridge. In: Davis EE, Mottl MJ, Fisher AT et al. (eds) Proceedings of the Ocean Drilling Program (ODP), College Station, TX, Scientific Results 139:395-410

Cheraldonné P, Jollivet D (1993) Videoscopic study of deepsea hydrothermal vent alvinellid polychaete populations biomass estimation and behaviour. Mar Ecol Prog Ser 95 $251-262$

Davis EE, Fisher AT (1994) On the nature and consequences of hydrothermal circulation in the Middle Valley sedimented rift: inferences from geophysical and geochemical observations. In: Davis EE, Mottl MJ, Fisher AT et al. (eds) Proceedings of the Ocean Drilling Program (ODP), College Station, TX, Scientific Results 139:695-717

Davis EE, Mottl MJ, Fisher AT et al. (eds) (1992) Proceedings of the Ocean Drilling Program (ODP), College Station, TX, Initial Report Leg 139

Davis EE, Mottl MJ, Fisher AT et al. (1994) Proceedings of the Ocean Driling Program (ODP). College Station, TX, Scientific Results Leg 139

Davis EE, Villinger $H$ (1992) Tectonc and thermal structure of the Middle Valley sedimented rift, northern Juan de Fuca Rudge. In: Davis EE, Mottl MJ, Fisher AT et al. (eds) Proceedings of the Ocean Drilling Program (ODP). College Station, TX, Initial Report 139:9-41

Delaney J, Hildebrand J (1993) RIDGE Observatory Experiment (ROBE), Summary report of a workshop held February 18-20, 1993, University of Washington, Seattle. RIDGE Office, University of New Hampshire, Durham, $\mathrm{NH}, \mathrm{p} 1-12$

Embley RW, Franklin JM (1993) ROV samples vents on Juan de Fuca Ridge. EOS 74(15):177, 181-182

Fiala-Médioni A, Boulègue J, Ohta S, Felbeck H (1993) Source of energy sustaining the Calytogena populations from deep trenches in subduction zones off Japan. Deep Sea Res 40:1241-1258

Fustec $A_{1}$ Desbruyères D, Junıper SK (1987) Deep-sea hydrothermal vent communities at $13^{\circ} \mathrm{N}$ on the East
Pacific Rise: microdistribution and temporal variations. Biol Oceanogr 4:121-164

Goodfellow WD, Franklin JM (1993) Geology, mineralogy and chemistry of sediment-hosted clastic massive sulfides in shallow cores, Middle Valley, northern Juan de Fuca Ridge. Econ Geol 88:2037-2068

Goodfellow WD, Peter JM (1994) Geochemistry of hydrothermally altered sediment, Middle Valley, northern Juan de Fuca Ridge. In: Davis EE, Mottl MJ, Fisher AT et al. (eds) Proceedings of the Ocean Drilling Program (ODP), College Station, TX, Scientific Results 139:207-289

I Jenry P, Foucher JP, Le Pichon X. Sibuet M, Kobayashi K, Tarits P, Chamot-Rook N, Furuta T, Schultheiss P (1992) Interpretation of temperature measurements from the Kaiko-Nankai cruise: modelling of fluid flow in clam colonies. Earth Planet Sci Lett 109:355-371

Hessler RR, Smithey WM, Boudrias MA, Keller CH, Lutz RA, Childress JJ (1988) Temporal change in megafauna at the Rose Garden hydrothermal vent (Galapagos Rift; eastern tropical Pacific). Deep Sea Res 35:1681-1709

Hessler RR, Smithey WM, Keller CH (1985) Spatial and temporal variation of giant clams, tubeworms and mussels at deep-sea hydrothermal vents. In: Jones ML (ed) The hydrothermal vents of the eastem Pacific: an overview. Bull biol Soc Wash 6:411-428

Johnson KS, Beehler CL, Sakamoto-Arnold CM, Childress JJ (1986) In situ measurements of chemical distributions in a deep-sea hydrothermal vent field. Science 231:1139-1141

Johnson KS, Childress JJ, Hessler RR, Sakamoto-Arnold CM, Beehler CL (1988) Chemical and biological interactions in the Rose Garden hydrothermal vent field. Deep Sea Res 35:1723-1744

Juniper SK, Martineu P, Sarrazin J, Gélinas Y (1995) Microbial-mineral floc associated with nascent hydrothermal activity at CoAxial Segment, Juan de Fuca Ridge. Geophys Res Lett 22:179-182

Juniper SK, Fisher CR, the BioROPOS '94 Shipboard Scientific Party (1994) A biological observatory at Endeavour Segment, Juan de Fuca Ridge. InterRidge News. InterRidge Offıce, University of Durham, UK 3(2):23-25

Juniper SK, Sibuet M (1987) Ecology of cold seep benthic communities in the Japan subduction zones: spatial organization, trophic strategies and evidence for temporal evolution. Mar Ecol Prog Ser 40:115-126

Juniper SK, Tunncliffe V, Southward EC (1992) Hydrothermal vents in turbidite sediments on a northeast Pacific spreading centre: organisms and substratum at an ocean drilling site. Can J Zool 70:1792-1809

Kennicut MC II, Brooks JM, Bidigare RR, Fay RR, Wade TL, MCDonald TJ (1985) Vent type taxa in a hydrocarbon seep region on the Louisiana slope. Nature 317:351-353

Kennish MJ, Lutz RA (1992) The hydrothermal vent clam, Calyptogena magnifica (Boss \& Turner 1980): a review of existing literature. Rev aquat Sci 6:29-66

Leybourne MI, Goodfellow WD (1994) Mmeralogy and mineral chemistry of hydrothermally altered sediment Middle Valley, Juan de Fuca Ridge. In: Davis EE, Mottl MJ, Fisher AT et al. (eds) Proceedings of the Ocean Drilling Program (ODP), College Station, TX, Scientific Results 139:155-206

MacDonald IR, Best SE, Lee CS, Rost AA (1992) Biogeochemical processes at natural oil seeps in the Gulf of Mexico field trials of a small area benthic imaging system (SABIS). Presented at: First Thematic Conference on Remote Sensing for Marine and Coastal Environments, New Orleans, LA, USA, June 15-17, 1992, Environmental Research Institute of Michigan, Ann Arbour, MI, p 1-12 
MacDonald IR, Boland GS, Baker JS, Brooks JM, Kennicutt MC, Bidigare RR (1989) Gulf of Mexico chemosynthetic communities. 11. Spatial distribution of seep organisms and hydrocarbons at Bush Hill. Mar Biol 101:235-247

MacDonald IR, Gunasso NL Jr, Sassen R, Brooks JM, Lee L, Scott KT (1994) Gas hydrate that breaches the sea floor on the continental slope of the Gulf of Mexico. Geology 22: $699-702$

Massoth GJ, Baker ET, Feely RA, Butterfield DA, Embley RE, Lupton JE, Thomson RE, Cannon GA (1995) Observations of manganese and iron at the CoAxial seafloor eruption site, Juan de Fuca Ridge. Geophys Res Lett 22:151-154

Nelson DC, Hagen KD (1995) Physlology and biochemistry of symbiotic and free-living chemoautotrophic sulfur bacteria. Am Zool 35:91-101

Rohr KM, Gröschel-Becker H (1994) Correlation of well logs, physical properties, and seismic reflection data, Middle Valley, Juan de Fuca Ridge. In: Davis EE, Mottl MJ, Fisher AT et al. (eds) Proceedings of the Ocean Drilling Program (ODP), College Station, TX, Scientific Results 139:585-596

Rohr KM, Schmidt U (1994) Seismic structure of Middle Valley near sites 855-858, Leg 139, Juan de Fuca Ridge. In: Davis EE, Mottl MJ, Fisher AT et al. (eds) Proceedings of the

This article was submitted to the editor
Ocean Drilling Program (ODP) College Station, TX, Scientific Results 139:3-17

Sarrazin J, Juniper SK, Massoth GJ (1993) Using the ROPOS remote vehicle to study biological and physico-chemical zonation on hydrothermal chimnys. EOS 74(43) Suppl. (abstr \#T21A-01)

Sibuet M, Juniper SK, Pautot G (1988) Cold seep benthıc communities in the and subduction zones: geological control of community development. $J$ mar Res 46:333-348

Tunncluffe V, Juniper SK (1990) Dynamic character of the hydrothermal vent habitat and the nature of the sulfide chimney fauna. Prog Oceanogr 24:1-13

Turner RJW, Ames DE, Franklin JM, Goodfellow WD, Leitch CHB, Hoy $T$ (1993) Character of active hydrothermal mounds and nearby altered hemipelagic sediments in the hydrothermal areas of Middle Valley, northern Juan de Fuca Ridge: shallow core data. Can Mineralogist 31:973-995

Tuttle JH, Jannasch HW (1979) Microbial dark assimilation of $\mathrm{CO}_{2}$ in the Cariaco Trench. Limnol Oceanogr 24:746-753

Zierenberg R, Becker K, Juniper SK (1994) Sediment covered ocean ridge experiments (SCORE). Report of a workshop sponsored by RIDGE/USSAC, July 29-30, 1994, Portland, OR. RIDGE Office, Woods Hole Oceangraphic Institution, Woods Hole, MA

Manuscript first recelved: December 14, 1994 Revised version accepted: May 16, 1995 